Review

\title{
Weed Management in Cranberries: A Historical Perspective and a Look to the Future
}

\author{
Hilary A. Sandler \\ University of Massachusetts-Amherst Cranberry Station, PO Box 569, East Wareham, MA 02538, USA; \\ hsandler@umass.edu; Tel.: +1-508-295-2212
}

Received: 13 August 2018; Accepted: 5 September 2018; Published: 8 September 2018

\begin{abstract}
Integrated weed management (IWM) has been part of cranberry cultivation since its inception in the early 19th century. Proper site and cultivar selection, good drainage, rapid vine establishment, and hand weeding are as important now for successful weed management as when the industry first started. In 1940, Extension publications listed eight herbicides (e.g., petroleum-based products, inorganic salts and sulfates) for weed control. Currently, 18 herbicides representing 11 different modes of action are registered for use on cranberries. Nonchemical methods, such as hand weeding, sanding, flooding, and proper fertilization, remain integral for managing weed populations; new tactics such as flame cultivation have been added to the toolbox. Priority ratings have been developed to aid in weed management planning. Despite many efforts, biological control of weeds remains elusive on the commercial scale. Evaluation of new herbicides, unmanned aerial systems (UAS), image analysis, and precision agriculture technology; investigation of other management practices for weeds and their natural enemies; utilization of computational decision making and Big Data; and determination of the impact of climate change are research areas whose results will translate into new use recommendations for the weed control of cranberry.
\end{abstract}

Keywords: herbicides; precision agriculture; big data; analytic hierarchy processing; flame cultivation; wet blade technology; unmanned aerial systems; weed priorities

\section{Introduction}

The American cranberry (Vaccinium macrocarpon Ait.) has a native range that extends from the temperate climates in the North Central U.S. and the Canadian province of Ontario to the U.S. East Coast and the Canadian provinces of Quebec and the Atlantic Maritimes [1]. Its western edge includes the U.S. states of California, Oregon, and Washington, and the province of British Columbia. The northern edge of its range includes the Artic Archipelago of the Queen Elizabeth, Banks, and Victoria Islands, and the Northwest Territory (Canada), and continues south in the Appalachians to the U.S. states of Tennessee and Kentucky. Located south of Newfoundland, the islands of St. Pierre and Miquelon (France) are also part of the native range. Cranberry is a low-growing, trailing, perennial vine that produces stolons (runners) $30 \mathrm{~cm}$ to $180 \mathrm{~cm}$ long. Short vertical branches, known as uprights, form from the buds along the runners. Uprights have terminal buds that contain the floral meristems. A member of the Ericaceae or heath family, cranberries prefer acidic soils ( $\mathrm{pH} 4-5)$; they can tolerate periodic flooding and still produce commercially viable crops. The cranberry primarily grown for global markets is the American cranberry. More than 75 cultivars have been identified for $V$. macrocarpon, and the proportion of selected cultivars varies by growing region [2]. The hybrid cultivar, Stevens (cv. Potter x cv. McFarlin), is grown throughout North America and is the predominant cultivar in many growing regions.

Data from 2017 indicated that the majority of the world's commercial plantings are in the U.S. (98,000 ha) and Canada (50,000 ha); in the southern hemisphere, Chile has 4200 ha in production [3]. 
Eastern Europe (e.g., Azerbaijan, Belarus, and Latvia) and the Netherlands, often cultivating the small or European cranberry ( $V$. oxycoccus), are minor but emergent production areas. Production is measured in "barrels", which are equivalent to $45.4 \mathrm{~kg}$ (100 lb). In 2017, the U.S., Canadian, and Chilean useable production was $8.08 \mathrm{M}, 2.65 \mathrm{M}$, and $0.48 \mathrm{M}$ barrels, respectively [4]; the current top three production areas are Wisconsin, Quebec, and Massachusetts. North American production has been growing over the past two decades due to new plantings of high-yielding cultivars in Eastern Canada coupled with renovation to high-yielding cultivars in the U.S. Cranberries are high in vitamin C, fiber, and phytochemicals (e.g., polyphenolics, proanthocyanidins), which are associated with health benefits $[5,6]$. Most cranberries $(>95 \%)$ are processed and consumed as juices, sauces, sweetened dried products, and nutritional supplements; the remainder are sold as fresh fruit.

To consistently supply the global market with high-quality fruit, growers perform a variety of horticultural and pest management tasks, such as pruning, nutrient application, and weed removal. Proper weed management maintains open space, allows the rooting and growth of new vines, and helps maximize the production of established (two years or more) cranberry plantings [7]. The impact of weeds and the decision-making processes that integrate chemical, cultural, and nonchemical strategies have economic ramifications on cranberry production; different weeds have been shown to cause different amounts of economic damage [8,9]. Average cranberry crop loss due to weeds has been reported to range from $15 \%$ to $25 \%$ [9]. Using the three-year average of utilized production and value of production from 2014-2016 data [10] and assuming reported yields were maximized due to the use of proper weed management during those years, estimated annual losses due to weeds could range from $\$ 40-67 \mathrm{M}$ for the U.S. cranberry crop (author's estimate).

In the decades following the inception of cranberry cultivation in 1816 [11,12], cranberry growers used similar tactics for weed management as growers of annual crops, such as hand weeding and the occasional application of chemicals such as sulfuric acid and copper sulfate. Tactics such as mechanical cultivation, use of no-till, and/or crop rotation are not feasible in cranberry cultivation. The inability to implement many conventional weed management strategies is due to the physical characteristic of historical and current cranberry horticulture: the production and maintenance of a continuous canopy of vegetation. This horticultural system is in stark contrast to the conventional modes employed in many agronomic and specialty crops, which use and optimize rows of plants. The use of this planting method affects both short- and long-term weed management decisions for the cranberry grower.

This paper provides a description and summary of weed management history, recent research, and outreach efforts, and speculation on possible future directions of weed management in cranberries. This paper was not intended to be a treatise on weed management for the entire industry. The intent was to summarize archival documents, dating back to 1856, which are housed at the University of Massachusetts (UMass) Cranberry Station, with a de facto emphasis on the Massachusetts perspective and experience. The successes and challenges of implementing weed control strategies in cranberries, through the lens of history, research, and extension, are discussed below.

\section{An Overview of Cranberry Horticulture}

\subsection{Bed Characteristics, Renovation, and Maintenance Activities}

The commercial cranberry production area (i.e., bog, bed, marsh) is typically the lowest part of the surrounding landscape and is comprised of perimeter and interior drainage ditches and dikes that can readily contain water. Due to the use of periodic flooding, beds are typically associated with nearby bodies of water such as ponds, rivers, or man-made reservoirs; some growers need to obtain their water from wells. Water control systems consist of flood gates, flumes, lift pumps, piping, and sprinkler heads. Flooding is used to manage insects, diseases, and weeds [13-16]. Vines are flooded in the fall for harvest and in the winter to prevent desiccation. Vines may also be flooded for 30 days in the spring, a practice known as "late water", for pest management benefits $[17,18]$. 
Historically, periodic renovation of cranberry plantings was not part of the typical business plan; once planted, vines could be "in the ground" for 30 years or more. However, the development of new, high-yielding varieties and increased pressure on a shrinking profit margin has forced growers to re-evaluate this expectation of longevity. In addition, during the productive life of the planting, the vine canopy can become degraded. For example, weed infestations become severe; the proportion of low-yielding, off-type (mongrel) vines increases; and the canopy becomes too thick to permit good air circulation and light penetration. Renovating and replanting are among the highest capital inputs that a cranberry grower will incur [19]. Once the decision to replant is in motion, all decisions and efforts revolve around maximizing the return on investment in the shortest time period possible. Renovating on a 20-25 year cycle is currently considered to be a reasonable business model that will promote farm sustainability [20].

Typical activities in renovation include the removal of existing vines with a bulldozer, laser leveling of the bog surface, the addition of approximately $10 \mathrm{~cm}$ to $20 \mathrm{~cm}$ of sand, fumigation, repairing or replacing irrigation systems, purchasing and planting new vines, and the application of fertilizers and herbicides [2,21]. Cranberry vines are planted either as rooted plugs, at a density of 11 plugs $\mathrm{m}^{-2}$, or as unrooted cuttings, which are scattered on the ground at densities ranging from $2250 \mathrm{~kg} \mathrm{ha}^{-1}$ to $4500 \mathrm{~kg} \mathrm{ha}^{-1}$. Planting activities are normally completed by late spring. Proper irrigation is critical, especially for unrooted cuttings, during the first few months. Scouting for insects is conducted every few weeks after vines are established; fungicides may be applied once or twice in the first year. Weed control efforts typically employ a combination of a pre-emergence herbicide (e.g., napropamide), a postemergence herbicide (e.g., mesotrione), and hand weeding.

The importance of proper fertilizer and weed management for bed establishment has been reported by early and recent cranberry scientists alike [2,11]. In the first year, fertilizer is applied in low doses every few weeks to promote stolon (runner) growth and colonize the production area; application frequency and dose are reduced in Year 2 and thereafter as vines become established [21]. A two-year evaluation of new planting establishment of cv. Stevens indicated that the most cost-efficient treatment combination for promoting vigorous vine growth was to plant vines at a low density $\left(1.8 \mathrm{Mg} \mathrm{ha}^{-1}\right)$, use moderate rates of nitrogen $\left(56 \mathrm{~kg} \mathrm{ha}^{-1}\right)$, and apply an annual application of the pre-emergence herbicide, napropamide [7]. Related research indicated that vine density, fertilizer, and weed management also interacted to affect the colonization (recovery) of disturbed areas in new plantings [22]. Disturbances may occur from localized injury from biotic or abiotic factors, such as pest or machine damage. Recovery is key to regaining maximum fruit productivity.

Once vines are established and yields are increasing, horticultural and pest management activities are modified to promote vine health and productivity. These include weekly scouting for pests, irrigation, frost protection, flooding, pesticide applications, use of commercial hives of honey (Apis mellifera (L.)) and bumble (Bombus impatiens (Cresson)) bees for pollination, ditch cleaning, and sanding. Irrigation is accomplished through a system of solid set rotating heads (e.g., impact, pop-up) connected to underground pipes. Pesticides are applied in numerous ways, with the predominant method varying by growing region. Examples of application methods include the irrigation system (chemigation), cantilever boom sprayers, ground equipment, or backpack sprayers. The periodic (every three to five years) application of a thin $(0.5-3 \mathrm{~cm})$ layer of sand on top of the vine canopy is a cultural practice that has both horticultural and pest management benefits [23].

The length of time from planting to first commercial harvest is typically two to five years and is influenced by multiple factors, including environmental conditions, cultivar selection, and management decisions. Cranberries (northern hemisphere) are harvested from early September through mid-November; exact harvest dates vary by region, weather conditions, and cultivar. The water harvester was introduced in the early 1950s and most cranberries are harvested in shallow flood waters using a water reel (or similar) that detaches the berry from the pedicel [24]. Floating berries are then corralled and lifted from the water via conveyor belts or vacuums. Less than $5 \%$ of the U.S. crop is "dry" harvested [25], a method introduced in the 1920s but not used regularly until 
the late 1940s. This method often utilizes mechanical, self-propelled, walk-behind pickers, but dry harvesting can also include the use of wooden scoops and picking by hand. Weed infestations can be particularly problematic for dry-harvesting machines, binding the mechanical parts and interrupting and delaying operations.

\subsection{Cranberry Weed Species, Integrated Weed Management, and Weed Priorities}

The presence of weeds in cranberry is a management concern for most growers. Most of the weed species in commercial cranberry are perennials, though annual plants can be problematic, especially on new plantings [26]. The term integrated weed management (IWM) includes the use of all available tactics to manage weeds within an agricultural system [27]. It is a decision-support system for the selection and use of weed control strategies, either singly or in combination, to achieve a desirable level of control. IWM is utilized regularly by cranberry growers.

Since weeds are non-motile, conventional scouting and threshold tactics (used for insects) needed to be modified to fit the cranberry system. A Priority Grouping system was developed in 1995 at the UMass Station to help growers plan their weed management approach [28]. This system categorized weeds into four groups based on a subjective evaluation of three criteria: ease of control, ability to spread, and impact on yield. During the creation of new weed identification guides in 2013 and 2015 (in French [29] and English [26], respectively), the prioritization concept was revised and expanded (Table 1). The Priority Rating of each weed was determined by assigning points to four criteria: impact, biological form or type, invasive and/or reproductive capacity, and adaptation to the cranberry habitat. Each weed is evaluated via the four criteria and assigned a value (either 1,2,4, or 8), and the sum of these determine the overall Priority Rating. The utility of this system lies in the fact that priority ratings can be tabulated based on a grower's experience with the weed in question and site-specific characteristics. The whole-farm weed management approach can then be easily geared to the individual needs, resources, and goals of the grower. Weeds receiving a very high or high Priority Rating according to this system are listed in Table 2.

Table 1. Criteria and points associated with determination of the priority rating of a weed in cranberry production systems according to Neron et al., 2013 and Sandler et al., 2015.

\begin{tabular}{|c|c|c|c|c|}
\hline \multirow[b]{2}{*}{ Points $^{1}$} & \multicolumn{4}{|c|}{ Criteria to Determine Priority Rating } \\
\hline & Impact & $\begin{array}{l}\text { Biological Form or } \\
\text { Type }\end{array}$ & $\begin{array}{c}\text { Invasive or Reproductive } \\
\text { Capacity }\end{array}$ & $\begin{array}{c}\text { Adaptation to } \\
\text { Cranberry Habitat }\end{array}$ \\
\hline 1 & Little effect & Annual plant & $\begin{array}{l}\text { Propagation by seed only } \\
\text { with few seeds produced }\end{array}$ & $\begin{array}{l}\text { Marginally adapted, } \\
\text { easy to pull }\end{array}$ \\
\hline 2 & $\begin{array}{l}\text { Reducing } \\
\text { yield }\end{array}$ & $\begin{array}{l}\text { Perennial or biennial, } \\
\text { producing shoots, few } \\
\text { rhizomes, stolons }\end{array}$ & $\begin{array}{l}\text { Propagation by seed only } \\
\text { with many seeds produced }\end{array}$ & $\begin{array}{l}\text { Marginally adapted, } \\
\text { hard to pull }\end{array}$ \\
\hline 4 & $\begin{array}{l}\text { Reducing } \\
\text { vine vigor }\end{array}$ & $\begin{array}{l}\text { Perennial plant, } \\
\text { different from } \\
\text { cranberry, producing } \\
\text { rhizomes, stolons }\end{array}$ & $\begin{array}{l}\text { Low to moderate stolons, } \\
\text { rhizomes, some propagation } \\
\text { via plant parts, seeds }\end{array}$ & $\begin{array}{l}\text { Well-adapted, easy to } \\
\text { pull }\end{array}$ \\
\hline 8 & $\begin{array}{l}\text { Killing or } \\
\text { crowding out } \\
\text { vines }\end{array}$ & $\begin{array}{l}\text { Perennial plant similar } \\
\text { to cranberry, extensive } \\
\text { rhizomes, stolons }\end{array}$ & $\begin{array}{l}\text { Vigorous production } \\
\text { rhizomes, stolons, } \\
\text { propagations via plant parts, } \\
\text { seeds }\end{array}$ & $\begin{array}{l}\text { Well-adapted, hard } \\
\text { to pull }\end{array}$ \\
\hline
\end{tabular}

1 Points assessed from the four criteria are summed to calculate Priority Rating: Low Priority $=1$ to 7 points; Medium Priority = 8 to 15 points; High Priority $=16$ to 23 points; and Very High Priority $=24$ to 32 points. 
Table 2. Listing of very high and high priority weed species for North American cranberry production, based on Sandler et al., 2015 and Neron et al., 2013.

\begin{tabular}{|c|c|}
\hline Latin Name & Common Name \\
\hline \multicolumn{2}{|c|}{ Very High Priority } \\
\hline Cuscuta gronovii Willd. ex Schult. & Swamp dodder \\
\hline Cyperus dentatus Torr. & Toothed flatsedge \\
\hline Lysimachia terrestris (L.) Britton, Sterns \& Poggenb. & Earth loosestrife \\
\hline Phragmites australis (Cav.) Trin. ex Streud & Common reed \\
\hline Polytrichum commune Hedw. & Haircap moss \\
\hline Rubus allegheniensis Porter & Allegheny blackberry \\
\hline Rubus hispidus L. & Bristly dewberry \\
\hline Smilax glauca Walter & Cat greenbrier \\
\hline \multicolumn{2}{|l|}{ High Priority } \\
\hline Agrostis scabra Willd. & Rough bentgrass \\
\hline Andropogon virginicus L. & Broomsedge bluestem \\
\hline Aronia melanocarpa (Michx.) Elliot & Black chokeberry \\
\hline Calamagrostis Canadensis (Michx.) P. Beauv. & Bluejoint \\
\hline Calystegia sepium (L.) R. Br. & Hedge false bindweed \\
\hline Carex chordorrhiza Ehrh. Ex L.F. & Creeping sedge \\
\hline Carex oligosperma Michx. & Fewseed sedge \\
\hline Clethra alnifolia $\mathrm{L}$. & Coastal sweetpepperbush \\
\hline Cyperus strigosus L. & Strawcolored flatsedge \\
\hline Euthamia graminifolia (L.) Nutt. & Flat-top goldentop \\
\hline Glyceria canadensis (Michx.) Trin. & Rattlesnake mannagrass \\
\hline Hypericum ellipticum Hook. & Pale St. Johnswort \\
\hline Juncus brevicaudotus (Engelm.) Fernald & Narrowpanicle rush \\
\hline Juncus effusus L. & Common rush \\
\hline Kalmia angustifolia L. & Sheep laurel \\
\hline Lachnanthes caroliniana (Lam.) Dandy & Carolina redroot \\
\hline Leersia oryzoides (L.) Sw. & Rice cutgrass \\
\hline Lycopus americanus Muhl. ex W.P.C. Barton & American water horehound \\
\hline Lycopus uniflorus Michx. & Northern bugleweed \\
\hline Lythrum salicaria L. & Purple loosestrife \\
\hline Muhlenbergia frondosa (Poiret) Fernald & Wirestem muhly \\
\hline Onoclea sensibilis L. & Sensitive fern \\
\hline Rumex acetosella L. & Common sheep sorrel \\
\hline Scirpus atrocinctus Fernald & Blackgirdle bulrush \\
\hline Scirpus cyperinus (L.) Kunth & Woolgrass \\
\hline Triadenum fraseri (Spach) Gleason & Fraser's marsh St. Johnswort \\
\hline
\end{tabular}

\section{Historical Weed Management, 1820-1960}

\subsection{First Cultivation and Early Weed Management}

Captain Henry Hall is recognized as the first person to cultivate the American cranberry (V. macrocarpon) in ca. 1820 in his "cranberry yard" in Dennis, MA [30]. Significant cultivation was noted to have started no earlier than 1850 for MA; the first vines were planted in New Jersey in 1845. One of the first cultivators from Burlington County, New Jersey makes mention of "handpulling grasses and huckleberry bushes (weeds there were none)". Plants used to identify a good location for cranberry vines are among those now considered to be weeds, such as sheep laurel (Kalmia angustifolia L.), leatherleaf (Cassandra calyculata (L.) Moench), and moss (Polytrichum commune Hedw. and Sphagnum L.). Even in 1870, growers had differing opinions of whether it was worth the money and effort to get a totally weed-free surface, simply to gain the "satisfaction of having one's ground free from eye sores". Tools mentioned specifically for weed management in site preparation were the bill-hook, brier-scythe, grubbing-hoe, and large iron-toothed rake.

In the early period of significant cranberry cultivation, several techniques were used to plant vines, including the use of furrows and "drills" (bundles of vines) in rows [30]. Once the vines were 
in the ground and established, growers relied on hoeing (first year only and dependent on planting method), hand-weeding, and trowels. The importance of controlling weeds in the first few years after "the setting of the vines" was also noted by Henry J. Franklin, the first field scientist to be located at the Massachusetts Cranberry Station facility [31]. The proliferation of healthy cranberry vines was and still is a good management tool that suppresses many annual weeds. Franklin perhaps deemed weed management to be a minor issue since weeds were only briefly mentioned towards the end of his first report on 1915 Station activities [32]. However, his writings throughout his tenure do indicate that an integrated approach (e.g., proper site selection, good drainage and water management, sand, variety selection, etc.) to guide one's weed, insect, and disease management decisions was the key to success in cranberry cultivation [33,34].

Works published on weed management prior to 1930 emphasized prevention, optimal site selection and preparation, promotion of good vine colonization in the first three years after planting, handpulling, removal of seed heads, flooding, and proper drainage. The importance of proper fertilization (enabling vines to outcompete weeds) and the use of sand were also reported to assist in weed control $[35,36]$. Franklin often notes the control afforded by the winter flood against many upland weed species [33]. "Blue vitriol" and "oil vitriol" (copper sulfate and sulfuric acid, respectively) were advertised in proceedings from the annual conventions of the (New Jersey) American Cranberry Growers' Association (ACGA) [37]. The use of sulfuric acid for the control of bracken fern (Woodwardia virginica (L.) Sm.) was recommended in a $1925 \mathrm{New}$ Jersey publication [38]. Its use for general weed control in bog establishment is noted by Franklin [33]. In the same publication, he notes that iron sulfate can be used to control "most ferns".

The results of further weed control studies, conducted in Massachusetts by Franklin, William H. Sawyer and Chester E. Cross, were first published in 1937 as wall charts that were distributed to the local grower community [39]. Recommendations for the use of kerosene, copper sulfate, sodium chloride, and sodium arsenate were listed on the charts (Figure 1). Nonchemical approaches such as holding a winter flood on June 1 for the control of small brambles and the use of a weed hook for the control of woody weeds were also included on many of the early charts. Although produced annually starting in 1937, the impacts of World War II likely also influenced the cranberry industry and no charts were published from 1942 to 1945 . The wall charts were updated and published in the original format through 1990, when they were formatted into a 16-page booklet layout, renamed "The Chart Book", and issued annually thereafter in book format. In 2018, a 100-page Chart Book was released, on a trial basis, as a multi-year document. Herbicides that have been mentioned on a recommendation chart during this 84-year period are listed in Figure 1. Being listed does not necessarily mean that applications to commercial bogs occurred in any particular year, it simply indicates that these materials were permitted for use on cranberry farms in Massachusetts in any listed year. 


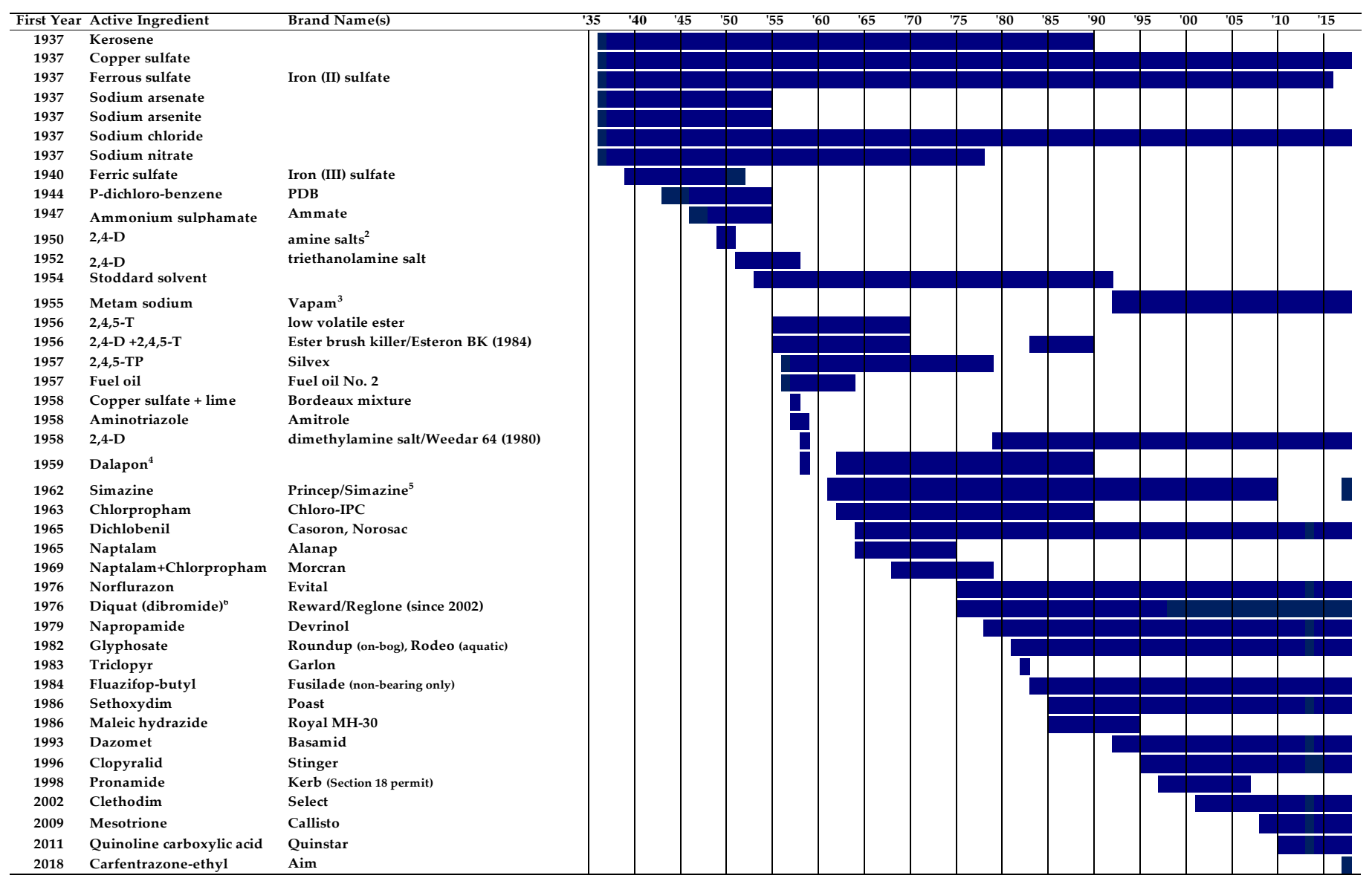

1. Sources: Massachusetts Cranberry Experiment Station Cranberry Charts, 1937-1990, Cranberry Chart Books 1991-2018 and pers. comm. (K. Ghantous). 2. Sodium, ammonium, and isopropanol. ${ }^{3 .}$ Registered for use on agricultural crops in 1955; records unclear when first use in cranberry was recommended. Fumigant use, in general, is noted in 1993 recommendations and that year is used as the start date. ${ }^{4}$. Dalapon was first used in mixture with aminotriazole in 1959 and was re-introduced as a solo application in 1963. ${ }^{5}$ Cranberries were removed from the Princep label in 2011 but re-registered under another simazine label for use in 2018

Figure 1. Historical listing of herbicides registered for use in cranberries, 1937-2018. Bar indicates years recommended and/or labeled for use; data derived from Massachusetts-based documents and personnel1. Although charts were not printed during 1942-1945, it is presumed that the compounds registered for use on cranberry remained registered during these World War II years. 
A flora was produced by Cranberry Station scientists ca. 1937 to aid in weed identification; it was appended with a short management chapter based on research efforts by Station scientists [40]. Both the flora and the 1937 chart acknowledged that kerosene afforded the control of many weeds, including earth (yellow) loosestrife (Lysmachia terrestris (L.) Britton, Sterns \& Poggenb.), devil's beggartick (Bidens frondosa L.), mannagrass (Glyceria obtusa (Muhl.) Trin.), woolgrass (Scirpus cyperinus), and many species of Carex. The flora authors note that "water white kerosene is the only petroleum product of real value for weed control". Pulverized copper sulfate was recommended (1938 chart) as a spray to control several weed species including nutgrass (Cyperus dentatus L.) and barnyardgrass (Echinochloa crus-galli (L.) P. Beauv.). Dry iron 'sulphate' (ferrous sulfate) was used against weeds including ferns (e.g., Osmunda regalis L., Woodwardia virginica), tearthumb (Polygonum sagittatum L.), pitchforks, cottongrass (Eriophorum virginicum L.), and wild bean (Apios americana Medik.); handfuls placed at the base of ferns and cottongrass were noted to be effective. It was also mentioned that a "good double handful of iron sulphate on a pitcher plant (Sarracenia L.) makes it forget about trapping insects forever" [40]. In the charts' inaugural year, copper sulfate was also listed for pitcher plant control. Ferric sulfate (1939-1952) was injurious to new vines, but when applied properly, could offer control of horsetail (Equisetum arvense L.). Sodium arsenate (1937-1955) or salt solutions were recommended for the control of wild bean. Salt solutions were also recommended in early charts and mid-century publications for the control of ferns and fireweed (Erechtites hieraciifolius (L.) Raf. ex DC.) [41] and they are still used occasionally to kill top growth of several weed species, including swamp dodder (Cuscuta gronovii Willd. ex Schlut.) and wild bean. Sodium chlorate is mentioned by Cross for the control of poison ivy (Toxicodendron radicans (L.) Kuntze) in the 1937 ACGA Proceedings [41], but the chemical was not included on the Massachusetts charts.

\subsection{Synthetic Herbicides and the Herbicide Revolution}

Compounds mentioned above (and in Figure 1, pre-1950) were the primary chemical options available for cranberry growers (and most other farmers as well) until the discovery, synthesis, and commercialization of the phenoxyacetic acid herbicides (e.g., 2,4-D) in the 1940s [42]. Part of a clandestine war effort to develop a compound that would significantly injure the enemy's crops, work was conducted by multiple groups of scientists in the U.S. and the United Kingdom during World War II $[43,44]$. The discovery and synthesis of these new chemistries marked the beginning of a new era of chemical weed control for all agricultural crops, including cranberry. 2,4-D was first made commercially available in the U.S. in 1945 and was first noted, as an amine salt, for use on cranberry in 1950 (Figure 1). Multiple forms of the phenoxy herbicides (e.g., 2,4,5-T and 2,4,5-TP) were used on cranberry. 2,4-D was first introduced in the dimethylamine form in 1959, for that year only. It was not seen on the chart recommendations again until 1980 (as Weedar 64) and has remained available as of this writing. 2,4-D combined with 2,4,5-T was used as Ester Brush Killer from 1956-1970. This combination was then re-introduced and briefly used as Esteron BK from 1984 to 1990. The combination of equal parts 2,4-D and 2,4,5-T, also known as Agent Orange, was used as a defoliant during the Vietnam War.

The number of available herbicides in 1940, 1950, and 1960 was 8, 11, and 10, respectively, which are lower figures than subsequent decades (Figure 1). The main weed control methods mentioned during the 1940s and 1950s included kerosene, Stoddard solvent (mineral turpentine), ferrous (often noted simply as 'iron sulfate') and ferric sulfate, copper sulfate, sodium arsenate, sodium arsenite, good drainage, hand-pulling, sanding, and mowing [34,41,45]. Starting in 1946 and ending in 1955, ammonium sulphamate and paradicholorobenzene (PDB) were listed on the charts for woody weed control. Recommendation of sodium arsenite and arsenate ceased in 1955, while kerosene remained on the charts until 1990 (Figure 1). Fuel oil No. 2 was listed to control ditch weeds for a short period (1957-1964) and copper sulfate (Bordeaux mixture) was listed for nutgrass, fireweed, and algae control for one year (1958). It should be noted that aminotriazole was listed for use with Dalapon in 
1959 , but this combination was dropped from the charts, likely due to the "cranberry scare of 1959" (see below). Dalapon was re-introduced as a solo application in 1963.

\subsection{The Cranberry Scare of 1959}

Cranberries hold the unenviable position in history of being the first food crop to be the subject of a national food scare [46]. The Delaney Clause (Food Additives Amendment) was enacted in 1958 and completely restricted the use of carcinogens in food; there was no amount of residue (i.e., zero tolerance) that was permissible, even if the detectable level posed no health risk. Aminotriazole, a new herbicide, was approved for postharvest use in cranberries in the same year the clause was enacted. Concurrently, data indicated that aminotriazole was linked to cancer in laboratory animals and that residues of aminotriazole might be detectable on cranberry fruit [46]. In an effort to avoid the serious consequences posed by the intersection of these emerging facts with the newly approved Delaney Clause, Ocean Spray Cranberries distributed a letter to its growers, dated 18 September 1959, asserting that growers should not use aminotriazole "in any manner, at any time". In a public press conference held on 9 November 1959, Health, Education and Welfare Secretary Arthur Fleming connected aminotriazole as a possible carcinogen to cranberries. The quick and intense public reaction to the news caused cranberry sales to plummet just prior to the peak distribution period (Thanksgiving market).

The cranberry industry lobbied government officials and won financial restitution within two years, but the Cranberry Scare had both short- and long-term repercussions on the industry and the interrelationships of handlers, researchers, and growers [47,48]. Shortly following the crisis, marginal cranberry acreage was taken of production and the U.S. acreage reached its low point [24]. In the following decades, the industry started shifting towards more productive varieties grown by fewer growers on larger acreage farms [2,24]. Other long-term consequences from the 1959 Cranberry Scare can be seen when current-day cranberry researchers apply for grant monies through cranberry industry partners. A waiver must be signed that commits the recipient to "not disclose or discuss" any unregistered compound as to forestall inappropriate use and/or subsequent residue detection of an unregistered product. In addition, cranberry handlers in all growing regions conduct annual pre-harvest residue testing on fruit prior to permitting delivery of the crop.

\section{Weed Management Research and Extension Efforts, 1960-Present}

\subsection{Herbicide Trends and Current Uses}

Post World War II, the discovery and production of commercial herbicides was quite rapid [44]. Between 1967 and 2014, the number of herbicides available for use on U.S. agriculture grew from 97 to 232 [49,50]. Cranberries experienced early rapid growth, with 17 new herbicides registered between 1950 and 1965, but in the subsequent 52-year period (1966-2018), only 15 products additional products were labeled for use in cranberry (Figure 1). Copper sulfate and sodium chloride are the only compounds that have remained listed on the charts for weed control since 1937. The actual number of products available for use for weed control was 10 in 1960 and reached a maximum of 18 in 1990 and 2018. Copper sulfate was recommended in the late 1930s through the 1950s for the control of moss, nutgrass, barnyardgrass, pitchforks, and algae (on flood waters); its use was narrowed to algal control in 1959. It is important to recognize that many of the weed control techniques recommended since the inception of cranberry cultivation have not been abandoned. The "tool kit" has simply become more diversified, mainly due to the acquisition of new herbicides with varied modes of action. The herbicides currently registered in the U.S. represent 11 modes of action (Table 3). 
Table 3. List of herbicides currently registered for use in cranberries in the United States. Registration and use patterns may vary among growing regions. Pre = pre-emergence; Post = postemergence.

\begin{tabular}{ccccc}
\hline Chemical Name & \multicolumn{2}{c}{$\begin{array}{c}\text { Mode of Action } \\
\text { WSSA HRAC }\end{array}$} & Pre/Post & Primary Target Weeds \\
\hline 2,4-D (liquid, granular) & 4 & O & Post & Broadleaves \\
Carfentrazone-ethyl & 14 & E & Pre & General plant control; burn down \\
Clethodim & 1 & A & Post & Grasses \\
Clopyralid & 4 & O & Post & Asteraceae, Fabaceae \\
Copper sulfate & NC & NC & Pre & Algae on flood waters \\
Dazomet & 26 & Z & Fumigant & General plant control \\
Dichlobenil & 20 & L & Pre & Broadleaves, dodder, monocots \\
Diquat bromide & 22 & D & Post & Aquatic plants, off-bog \\
Fluazifop-butyl & 1 & A & Post & Grasses (non-producing bogs) \\
Glyphosate & 9 & G & Post & General plant control \\
Mesotrione & 27 & F2 & Pre or Post & Broadleaves, dodder, grasses \\
Metam-sodium & 26 & Z & Fumigant & General plant control \\
Napropamide & 15 & K3 & Pre & Broadleaves, grasses \\
Norflurazon & 12 & F1 & Pre & Monocots \\
Quinclorac & 4 & O & Pre or Post & Dodder, grasses \\
Sethoxydim & 1 & A & Post & Grasses \\
Simazine & 5 & C1 & Pre & Broadleaves, grasses \\
Sodium chloride & NC & NC & Post & Burn down, selected plants \\
\hline
\end{tabular}

${ }^{1}$ Weed Science Society of America mode-of-action classification and Herbicide Resistance Action Committee classification. $\mathrm{NC}=$ not classified.

Irving "Dee" E. Demoranville and Robert M. Devlin continued weed control research and extension activities at the UMass Cranberry Station from ca. 1960 to 1995. They developed early use pattern recommendations for dichlobenil [51], napropamide [52], simazine, norflurazon [53], glyphosate [54], fluazifop, and sethoxydim. These herbicides are still available for use on U.S. cranberry farms today (Figure 1). Dalapon (1959-1998) and chloropropham (1963-1998) had significant registration durations for use on cranberries, but are no longer allowed in commercial cranberry production. Extension bulletins with photographs and weed management recommendations, building upon the work done by Cross [41,45], were published by Demoranville in the mid-1980s [55,56].

Several herbicides registered during the Demoranville-Devlin period had much shorter tenures in the cranberry industry: naptalam (1965-1975), the combination of chloropropham and naptalam (1969-1979), triclopyr (1983), and maleic hydrazide (1986-1995). Iron sulfate continued to be recommended for the control of ferns and moss though dichlobenil was easier to apply, less expensive, and typically more effective [55,57]. Setting the stage for future registrations, exploratory research into efficacy and crop safety was conducted for clopyralid [58], which was registered in 1996. Current registrations for clethodim, mesotrione, quinoline carboxylic acid (quinclorac), and carfentrazone-ethyl were supported by the coordinated efforts of the members of the North American Cranberry Research and Extension Workers (NACREW) Weed Working Group, regional grower associations, the Cranberry Institute, and the respective registrants. Research results are largely unpublished data sets but some projects have reached the peer-reviewed literature [59-62].

Herbicides currently registered for use on cranberries in the U.S. are listed in Table 3. Pre-emergence and postemergence herbicides are typically applied by chemigation, boom, or ground equipment. Postemergence compounds are typically applied by backpack sprayers or wipers. Use patterns are developed and recommended to minimize phytotoxicity to the cranberry vines [63]. Even with the current suite of 18 herbicides, control of certain weeds remains elusive. Chemical options that provide economical and consistent control of high priority weeds such as dewberry, sawbrier, poison ivy, loosestrife, and dodder are needed. Options for lower priority weeds such as maple (Acer rubrum L.) and emerging weed problems such as moss and common reed (Phragmites australis 
(Cav.) Trin. ex Streud) are also desirable since these species significantly interfere with vine health and yield production, as well as general maintenance and harvest operations.

\subsection{The Evolving Status of Herbicide Registrations and Export Markets}

Herbicide registrations have changed status through the years, usually due to regulatory changes and/or interpretation. It is not clear why 2,4-D (amine salt and dimethylamine salt) and the copper sulfate + lime combination had only one or two years on the charts as herbicides in the 1950s (Figure 1). Triclopyr did not receive a food tolerance and its use was revoked in the same year of its approval (1983). Pronamide was available for use on Massachusetts cranberry farms through Section 18 Emergency Exemption permits from 1998 through 2007; the herbicide is efficacious against dodder and some grasses [64,65]. Full registration was not forthcoming due to carcinogenicity concerns and the U.S. Environmental Protection Agency (EPA) denied any further exemption requests in 2007. The herbicide was reformulated for use on leaf lettuce and now has a reduced carcinogenicity profile [66]. Cranberries have been added to the label and full registration is projected to occur in 2019, which would put pronamide back in the Chart Book. Iron sulfate, used for moss control since 1937, was dropped from the 2017 Chart Book since it lacked technical labeling as a pesticide [67].

The importance of the export market for the cranberry industry has delayed the widespread adoption of new herbicides (and other pesticides) on cranberry farms, not only in Massachusetts, but throughout the U.S. Most fruits and vegetables entering foreign markets are subject to nation-established maximum residue limits (MRLs). The hurdle is that if an MRL has not been established for a particular crop in a particular country, the usual default for the threshold is $0.01 \mathrm{ppm}$. Residue detections readily exceed this very low limit and the fruit will not be allowed to enter the foreign market. To avoid the rejection of transported fruit to Europe, Asia, and elsewhere, cranberry handlers impose restrictions on the use of certain pesticides until data-based thresholds can be established. This process can take many years and significantly forestalls the use of a pesticide. For example, quinclorac was approved by the EPA for use on cranberry in 2011, but an MRL is yet to be established for the European Union (EU), a major market for exported cranberries. Since an EU-MRL is not established and handlers may not be equipped to segregate treated fruit bound for multiple export markets, quinclorac is rarely used for weed control unless the fruit is destined to stay within the U.S. (domestic market).

\subsection{Other Commercial Products, Biological Control, and Volatiles}

A small but steady interest persists in terms of evaluating nontraditional products for weed control. Multiple applications of a household degreaser decreased the biomass of dodder, but the manufacturer was not interested in pursuing a herbicide label for this product [68]. A recent evaluation of corn gluten meal, known for its weed suppression properties, proved to be a viable nitrogen source, encouraging both cranberry vine and weed growth, but provided no significant weed control [69]. Properly timed soil drenches with diluted vinegar were efficacious for controlling false lily-of-the-valley (Maianthemum dilatatum (Alph. Wood) A. Nelson \& J.F. Macbr.); vinegar showed potential to control marsh violet (Viola palustris L. and California blackberry (Rubus ursinus Cham. \& Schltdl. [61] and haircap moss [62].

Management of other pests with approved pesticides can affect the intensity of weed pests such as dodder. Anecdotal observations indicate that dodder infestations are diminished or absent when the use of the broad-spectrum fungicide, chlorothalonil, is reduced or eliminated. Speculation is that the increased use of selective fungicides (e.g., prothioconazole) and/or the reduction or elimination of broad spectrum fungicides for fruit rot control are conserving the natural enemies of dodder and the populations of the parasitic plant are reduced to a tolerable level.

Biological control of weeds in cranberry remains elusive. Thomas A. Bewick discovered a fungal species that would infect dodder (C. gronovii and C. compacta Juss.) and had success infecting the parasitic plant with lab-prepared spore solutions [70]. A commercial product was developed using 
Alternaria destruens E.G. Simmons strain 059 as a biocontrol agent. A. destruens was formulated as both a solid granular and a wettable powder. Several years of study in Massachusetts with both products failed to produce satisfactory control [71]. The resounding failure of this initial product in cranberries has hampered further commercialization of isolates from the field. In citrus, however, control of another dodder species, Cuscuta pentagona Engelm., was documented when A.destruens was mixed with glyphosate and ammonium sulfate [72]. Isolates of other fungi, Collectotrichum gloeosporiodes (Penz.) Penz. \& Sacc. and C. acutatum J.H. Simmonds, have proven virulent against dodder in field studies [73], but attempts to bring these biocontrol agents to commercialization have been unsuccessful to date. Other fungal pathogens of weeds have been isolated (e.g., Fusarium oxysporum Schltdl. and other Fusarium spp. on loosestrife), but limited resources of time and money have curtailed research efforts to develop these fungi as possible biocontrol agents.

Work with a bacteria-derived phytotoxin has shown some promise. A crude extract of Pseudomonas syringae (strain 3366) was sand-applied and reduced the root and shoot growth of four different weed species. Root and shoot growth of cv. McFarlin cranberry vines was reduced, but cv. Stevens were not adversely impacted [74]. Attempts were made by the authors towards commercialization, but were not successful.

Growers have long reported that dodder infestations seemed less intense on cv. Early Black. A greenhouse test of dodder performance on five different cranberry cultivars indicated that host attractiveness to dodder (i.e., the number of successful attachments) was lower in Early Black than for the other four cultivars, but this was not correlated with any measured volatile response. Parasitism by dodder was associated with increased levels of salicylic acid for all cultivars [75]. Subsequent work found that damage from herbivory by gypsy moth, Lymantria dispar (L.), to cranberry hosts reduced dodder attachment by nearly $50 \%$ one week after damage [76].

\subsection{Nonchemical and Cultural Weed Management}

\subsubsection{Late Water, Short Spring Floods, Summer Floods, and Fall Floods}

Starting in the 1990s, research efforts have focused on broadening the understanding and use of floods for insect, disease, and weed control. Studies on the use of late water (LW) floods (i.e., reflooding after the withdrawal of the winter flood for 30 days, starting mid-April) demonstrated that insect and disease pest life cycles were disrupted enough to reduce pesticide inputs $[13,18]$. Weeds were not specifically monitored by Averill et al., but anecdotal observations indicate that the LW floods do not impact weed populations. Holding a three to four week flood in the fall was inconsistent regarding the reduction of dewberry crown number, but reduced cranberry fruitworm, Acrobasis vaccinii (Riley), hibernacula emergence compared to unflooded beds [14]. Holding a long summer flood (10-12 May through 15-20 July) has been recommended since the 1974 chart targeting dewberry populations, and may impact other weed species present on the bog. This is a desperate measure that results in crop elimination in the year of the flood. A 10-day flood in July reduced species richness and weed cover for several broadleaf weed species [77].

The implementation of new uses for traditional flooding practices proved more effective for dodder control. In Wisconsin, the timing for the control of black-headed fireworm larvae was a $24-48 \mathrm{~h}$ flood in mid-May [78]. Anecdotal observations in the late 1990s indicated that some dodder populations were suppressed on Massachusetts beds when a short spring flood was held. Field studies indicated that 24-48 h floods in mid-May may offer a sustainable option that could be integrated into the overall management plan for dodder [15]. Subsequent work indicated that the floods may retard dodder stem growth rather than reduce seed germination [79].

\subsubsection{Hand-Held Flame Torches}

Flame cultivation (FC) is a nonchemical method of weed control where target plants are damaged or eradicated by brief exposure to high temperature. Cranberry vines recovered after treatment 
with open flame (OF) or infrared (IR) torches [80]. Many of the target weeds can be controlled with glyphosate, but FC can be less expensive and used in organic situations, and cranberry vines can recover from treatment with FC, whereas glyphosate treatments are often lethal [81]. Biomass collected in the year after treatment showed that two exposures of $9 \mathrm{~s}$ with an OF torch were more effective at reducing dewberry total, shoot, and root biomass than treatments that received a single exposure [82]. The efficacy of FC on dewberry control was impacted by both the timing and the frequency of treatments. Control of rushes (Juncus effusus L.) varied by torch type, with OF requiring shorter exposure durations than IR torches ( $8 \mathrm{~s}$ versus $60 \mathrm{~s}$ ) to achieve similar results [83]. Clipping followed by FC treatment reduced the number of rush stems more than clipping alone.

\subsubsection{Sand Applications and Mechanical Removal}

The periodic application of thin layers of sand is a typical horticultural practice in cranberry and can have pest management benefits [2]. Sanding has been shown to impact the annual weed, dodder. In greenhouse studies, applications of sand reduced dodder seedling emergence, but did not affect the survival time of seedlings [84]. At least $2.5 \mathrm{~cm}$ of sand was needed to reduce the emergence of dodder seedlings. Sanding may be used as part of a program consisting of combinations of multiple management methods directed toward the control of dodder. Care must be taken however, as sand piles have been identified as significant sources of weed seeds [85]. Burial of dewberry plants by sand depths typically used by growers $(<2.5 \mathrm{~cm})$ did not prevent emergence of the plant. Although reduced in number and biomass, dewberry still emerged from burial under $20 \mathrm{~cm}$ of sand [86].

Mowing of weeds, with tractor-driven machinery or hand-held string trimmers, on the bog and on the dikes is a routine practice that minimizes seed production and removes weed biomass. Mowing is particularly important for the removal of grass seed heads due to the numerous seeds produced by these plants. Often, shovels are needed to remove tussock-forming plants like rushes. Raking with a wooden or metal tool is often used to remove dodder stems and open the cranberry canopy to improve light penetration. Studies have produced varying results, with one indicating ineffectiveness [87], while another indicated that percent dodder cover was reduced by $>74 \%$ with one raking event and that raking more than once gave no additional benefit [88]. Weed wrenches (i.e., tools with a gripper plate that use a fulcrum to remove the plant) can be used for pulling out small woody plants. They are less effective when the plant has been cut numerous times, encouraging the development of a large crown.

\section{Future Directions for Weed Management in Cranberry}

The use of herbicides will continue to be an important component of IWM for conventionally grown cranberries in the 21st century. Thus, efforts should continue to evaluate new chemistries that exhibit good crop safety and weed control efficacy. Personnel should be trained and maintain their knowledge of good laboratory practices (GLP) and continue to secure priority rankings within IR4, the federal agency that facilitates the registration of pest management technology for specialty crops. The impact of management practices (chemical and nonchemical) on weed pests should continue. For example, researchers can investigate if farm practices could be manipulated to impact dodder "sensing" and deter attachment to cranberry and other susceptible hosts, as well as determine the role of fungicide use and survival of natural enemies of weeds, such as loosestrife. Certainly, the pursuit of the commercialization of biocontrol agents should remain a component of cranberry IWM [89]. In addition to understanding the impact of changing environmental conditions and the intensity of meteorological events on cranberries and weeds, new areas of research could include topics that utilize technology and emphasize the interface of precision agriculture and pest management. These are discussed in more detail below. 


\subsection{Climate Change}

Weeds are likely to be very resilient and adaptive to changes in carbon dioxide concentrations and rising temperatures [90]. Future research should consider the physiological adaptive capacity (i.e., $\mathrm{C}_{3}$ vs. $\mathrm{C}_{4}$, etc.) of weeds when developing recommendations for management in cranberry. Examination of environmental conditions (e.g., high temperatures, reduced water availability) on weed fecundity and crop-weed competition are worthy of future research efforts [91]. The impact of climate change on herbicide efficacy may vary among and within modes of actions [92] and warrants further investigation regarding its impact on cranberry weed control. Resistance management education may need revision based on research results on climate change and weed control [93].

\subsection{Decision-Making Approaches and other Computational Analytics}

Scientists currently working in cranberry research are engaged in the early stages of developing novel methods to analyze data generated by growers [94]. Limitations to spurring progress in the cranberry industry can be tied to obtaining adequate funding for supporting personnel. The interface of computational prowess with farming presents great opportunity for growth in precision agriculture, but as with many emerging technologies, the risks of early adoption and ramifications of failure cannot be ignored [95] and are most often borne by the farmer.

\subsubsection{Multi-Criteria Decision Making}

Analytical Hierarchy processing (AHP) can be described as a mathematical model of multi-criteria decision making (MCDM) that uses pairwise comparisons, in conjunction with a ratio scale, to indicate the strength of the preference or importance of various criteria [96]. AHP enables users to set priorities and make decisions when both quantitative and qualitative elements need to be considered. Its adaptation to the realms of biology and agriculture has been slow, but opportunity exists to use MCDM in many aspects of IPM and IWM in cranberries. In the future, research and extension efforts would provide a framework where cranberry growers engage a decision-support system to select and use weed control strategies, either singly or in combination, to achieve a desirable level of control.

Dodder was selected as an AHP case study as its management is not straight-forward; no single tactic provides adequate control across years and location [97,98]. AHP is especially attractive for this particular weed problem because it organizes both tangible (e.g., chemical efficacy) and intangible factors (e.g., a grower's experience or preference) in a systematic way. The use of flowchart software such as SimpleMind Desktop (v1.12.1591 for Mac, ModelMaker Tools, BV, Netherlands), may prove helpful to represent the most important criteria that growers must consider in an easy-to-understand flow chart type diagram. The maps can then be used to generate ratio-scaled surveys specifically designed so the results can be entered into a spreadsheet containing the formulas to prioritize the selected criteria. Input from stakeholder focus groups is key to ensure that the correct criteria are included [99]. Cranberry growers were highly receptive to using AHP in the dodder case study, and future survey processes should be simplified so that results can be easily accessible and interpretable.

\subsubsection{Big Data and Machine Learning}

The dictionary defines "Big Data" as extremely large data sets that may be analyzed computationally to reveal patterns, trends, and associations, especially relating to human behavior and interactions. It is a fairly new concept that holds intrigue and possibility for agriculture, including cranberries. A recent review indicates that the use of Big Data in farming is still in the developmental stage [100]. The cranberry industry is poised to develop and engage the tools to be a pioneering leader in this emerging field. Cranberry growers collect and report a robust data set each season to satisfy cranberry processor requirements related to traceability and risk. Work is already underway to obtain funding to use innovative Big Data analytics and machine learning to move precision agriculture from 
a decision-support tool to a decision-making system for the cranberry industry [101]. Jed Colquhoun (U. Wisconsin-Madison) is leading the effort to create an online simulated bog interface, similar to that used in gaming, which will allow growers to change inputs, weather, and bog characteristics to project yield and net return. Opportunity exists to utilize existing robust grower data sets with the novel analytics to provide practical results to growers. Successful development could enable growers to "farm online" before enacting real-life decisions on their farms, reducing risk associated with implementing data-driven changes.

\subsection{Precision Agriculture and Application Technology}

\subsubsection{Wet Blade Technology}

Wet Blade (WB) technology takes advantage of "vascular (xylem-phloem) snap". Vascular cells of plants are arranged in a way that they hold plant fluids in "columns" under tension in normal conditions. When a cut is made to a stem, the fluids "snap" back (i.e., the tension is broken) into the remaining stem and root system. A WB device simultaneously applies a fluid as it cuts and is specifically designed to apply the solution to the portion of the plant that remains in the ground. The technology provides control of annual and/or perennial weeds and limits re-sprouting [102]. Hand-held wet blade pruners effectively delivered herbicides to cut stems of common cranberry weeds [103]. Development and demonstration of mechanized and/or motorized hand-held WB technology is an area of exploration that has the potential to increase effective tactics for cranberry IWM.

\subsubsection{Unmanned Aerial Systems, GIS, and Remote Sensing}

Agriculture has been identified as one of the major industries poised to capitalize on the use of unmanned aerial systems (UAS) [104]. Expectations are that UAS will provide various services for farmers, as well as serve as tools for extension demonstration and data collection for agricultural researchers. Precision application of pesticides, based on UAS-collected data, should translate into reduced environmental impacts and improved yields. High-value crops, such as specialty fruit and vegetables, could benefit greatly from this technology; UAS have already demonstrated savings of $\$ 30 /$ ha for corn [105]. A recent survey conducted by the UMass Cranberry Station during the annual grower meeting demonstrated that over $60 \%$ of cranberry growers would like to see UAS incorporated into research and extension programs and that at least $25 \%$ of the respondents envision using a drone on their farms. Preliminary work has started at the UMass Cranberry Station to use UAS for weed mapping, as well as evaluating plant response to water stress and heat imbalances. Scouting and site-specific problem diagnoses are prime areas for IWM in which UAS could play a significant role. The irregular shapes of many Massachusetts cranberry fields could benefit immensely from the development of precision agriculture technology where chemicals can be applied without generating additional foot traffic in the production area. Another aspect of precision agriculture includes the use of geographic information systems (GIS) and remote sensing. Image processing methods, such as normalized difference vegetation index (NDVI), have been used to categorize variation in the cranberry yield [106]. The incorporation of aerial and satellite imagery with GIS has been used for cranberry disease assessment [107] and the usefulness of this technology for assessing and identifying weed infestations certainly warrants further consideration.

\subsubsection{Novel Applicators and Planting Arrangements}

Pushed by economic necessity, Massachusetts growers are building specialized application machines that deliver a high target efficiency. The directed application is delivered by sprayers mounted on vehicles that ride directly on the vines. Repeated use of the equipment injures and eventually kills the cranberry vines, creating bare strips or tracks in the otherwise continuous vine canopy. Achieving an upgraded performance of the product through the improved application is viewed to offset the loss of yield from the sacrificed vines. Determining the optimal portion of the 
production area that can be forfeited to maximize yield on the remaining portion through improved application precision is worthy of exploration. From a weed management perspective, the potential to apply herbicides to parts of the farm where the crop is not growing holds many advantages. The concept of forfeiting a portion of land to improve management options and yield can be taken even further. The intentional planting of cranberry vines in rows or raised beds, such as was done in the mid 1800s [30], warrants examination to determine if this early horticultural construct of vine planting could have a place in 21 st century cranberry farming.

\section{Conclusions}

Integrated weed management has been a successful construct for cranberry growers; current evidence and trends indicate that IWM will continue to serve the industry well. Most weeds in cranberry farming are perennial and long-term strategies must be used to curtail and/or eliminate problematic weed species. Weeds do differ in their impact on cranberry yield and some species may warrant a higher priority than other species. The prioritization of problematic weed species will vary by their abundance and negative impact on cranberry vines, the grower's resources (e.g., time and money), and the degree of importance of the aesthetics of the farm property.

Globalization of markets and proliferation of communication outlets (e.g., social media) have and will continue to influence agriculture and weed management, as well as many other spheres of society. As much as cranberry growers might prefer to remain out of politics, global economics and world politics will continue to impart forces (e.g., tariffs, MRLs) that affect decision making on local farming operations, such as weed control. As with other agricultural producers, successful cranberry growers of the future will need to understand basics of weed biology, have a facility with the digital world and its equipment, be good stewards of the land, and show resilience with shifting economic and environmental events.

Research and extension efforts will remain an important, if not invaluable, resource to secure the sustainability of cranberry farms in all the growing regions in the world. As in the early days of cranberry cultivation, the exchange of information amongst people working towards the common goal of producing a high-quality cranberry crop is the key to success. The scientists who have worked at the University of Massachusetts Cranberry Station and their colleagues throughout North America have been committed to finding answers for growers' problems and disseminating that information to the grower community. If history is any indication, future efforts that uncover environmental and economic solutions for pest management will carry the cranberry industry well into the 21st century and beyond.

Funding: This research received no external funding.

Acknowledgments: The author gratefully acknowledges the multi-year industry support (Cape Cod Cranberry Growers' Association (CCCGA), The Cranberry Institute, Cranberry Research Foundation and Ocean Spray Cranberries, Inc.) of the UMass Cranberry Station Weed Research and Extension Program. The author acknowledges Silent Spring Institute, Newton, Massachusetts (silentspring.org) personnel who assembled general historical cranberry pesticide date data that were used as the basis to construct Figure 1. Funds given by CCCGA were used to cover the costs to publish in open access. The author thanks C. DeMoranville, R. Serres, L. Hendrickson, and anonymous reviewers for their comments on the manuscript.

Conflicts of Interest: The author declares no conflict of interest.

\section{References}

1. The PLANTS Database. Available online: http:// plants.usda.gov (accessed on 25 August 2018).

2. Sandler, H.A.; DeMoranville, C.J. Cranberry Production: A Guide for Massachusetts; University of Massachusetts Extension Publication CP-08: East Wareham, MA, USA, 2008.

3. Cranberry Production Statistics. Available online: https://www.statista.com/ (accessed on 21 August 2018).

4. Cranberry Institute. Crop Statistics. Available online: https://www.cranberryinstitute.org/about_cran/ Cropstatistics_about.html (accessed on 21 August 2018). 
5. Kresty, L.A.; Howell, A.B.; Baird, M. Cranberry proanthocyanidins induce apoptosis and inhibit acid-induced proliferation of human esophageal adenocarcinoma cells. J. Agric. Food Chem. 2008, 56, 676-680. [CrossRef] [PubMed]

6. Neto, C.C.; Amoroso, J.W.; Liberty, A.M. Anticancer activities of cranberry phytochemicals: An update. Mol. Nutr. Food Res. 2008, 52, S18-S27. [CrossRef] [PubMed]

7. Sandler, H.A.; DeMoranville, C.J.; Autio, W.R. Economic comparison of initial vine density, nitrogen rate, and weed management strategy in commercial cranberry. HortTechnology 2004, 14, 267-274.

8. Patten, K.D.; Wang, J. Cranberry yield and fruit quality reduction caused by weed competition. HortScience 1994, 29, 1127-1130.

9. Swanton, C.J.; Harker, K.N.; Anderson, R.L. Crop losses due to weeds in Canada. Weed Technol. 1993, 7, $537-542$. [CrossRef]

10. Massachusetts Cranberries: 2016 Massachusetts Cranberry Crop Down 4 Percent from Previous Year. Available online: https://www.nass.usda.gov/...by.../2016\%20MA\%20Cranberry\%20Release.pdf (accessed on 9 July 2018).

11. Eastwood, B. The Cranberry and its Culture: A Complete Manual for the Cultivation of the Cranberry; Orange Judd and Company: New York, NY, USA, 1856.

12. Thomas, J.D. Cranberry Harvest: A History of Cranberry Growing in Massachusetts; Spinner Publication: New Bedford, MA, USA, 1990.

13. Averill, A.L.; Sylvia, M.M.; Kusek, C.C.; DeMoranville, C.J. Flooding in cranberry to minimize insecticide and fungicide inputs. Am. J. Alt. Agric. 1997, 12, 50-54. [CrossRef]

14. DeMoranville, C.J.; Sandler, H.A.; Shumaker, D.E.; Averill, A.L.; Caruso, F.L.; Sylvia, M.M.; Pober, D.M. Fall flooding for management of cranberry fruitworm (Acrobasis vaccinii) and dewberry (Rubus hispidus) in Massachusetts cranberry production. J. Crop Prot. 2005, 24, 999-1006. [CrossRef]

15. Sandler, H.A.; Mason, J. Flooding to manage dodder (Cuscuta gronovii) and broad-leaved weed species in cranberry: An innovative use of a traditional strategy. Renew. Agric. Food Syst. 2010, 25, 257-262. [CrossRef]

16. Teixeira, L.A.F.; Averill, A.L. Evaluation of flooding for cultural control of Sparganothis sulfureana (Lepidoptera: Tortricidae) in cranberry bogs. Environ. Ent. 2006, 35, 670-675. [CrossRef]

17. Beckwith, C.S. Late Holding of Water on Cranberry Bogs, Circular No. 402; New Jersey Agricultural Experiment Station: New Brunswick, NJ, USA, 1940.

18. Averill, A.L.; Averill, M.M.; DeMoranville, C.J. Alternative management strategies: Impact of late water on cranberry fruitworm and mites. Cranberries 1994, 58, 4-23.

19. Massachusetts Cranberry Cost of Renovation Study; Cape Cod Cranberry Growers' Association: Plymouth, MA, USA, 2009.

20. Wick, B.; Cape Cod Cranberry Growers' Association, Plymouth, MA, USA. Personal communication, 2017.

21. DeMoranville, C.J.; Sandler, H.A.; Caruso, F.L. Planting New Cranberry Beds. Available online: http: / / scholarworks.umass.edu/cranberry_factsheets/10/ (accessed on 23 July 2018).

22. Sandler, H.A. Nitrogen rate, vine density, and weed management affect colonization of cranberry beds following disturbance. Weed Technol. 2009, 23, 324-328. [CrossRef]

23. Cross, C.E.; Demoranville, I.E. Resanding of Massachusetts cranberry bogs; Publication No. 36; University of Massachusetts Cooperative Extension: East Wareham, MA, USA, 1969.

24. Eck, P. The American Cranberry; Rutgers University Press: New Brunswick, NJ, USA, 1990.

25. Cranberry Highlights, 2013-2015. Available online: https://www.nass.usda.gov/Statistics_by_State/New_ Jersey/Publications/Cranberry_Statistics/CRAN\%20Aug_4pg.pdf (accessed on 25 August 2018).

26. Sandler, H.A.; Dalbec, L.; Ghantous, K.M. Identification Guide for Weeds in Cranberries; Centre de Reference en Agriculture et Agroalimantaire du Quebec (CRAAQ): Quebec, QC, Canada, 2015.

27. Shaw, W.C. Integrated weed management systems technology for pest management. Weed Sci. 1982, 30, $2-12$.

28. Else, M.; Sandler, H.A.; Schluter, S. Weed mapping as a component of integrated pest management in cranberry production. HortTechnology 1995, 5, 302-305.

29. Neron, R.; Deland, J.P.; Drolet, I.; Painchaud, J. Guide D'identification des Mauvaises Herbes de la Canneberges; Centre de Reference en Agriculture et Agroalimantaire du Quebec (CRAAQ): Quebec, QC, Canada, 2013.

30. White, J.J. Cranberry Culture; Orange Judd and Company: New York, NY, USA, 1870.

31. Franklin, H.J. Cranberry Growing in Massachusetts, Circular No. 41; Wright and Potter Printing Co.: Boston, MA, USA, 1915. 
32. Franklin, H.J. Report of Cranberry Substation for 1915; Vol. Bulletin No. 168; Massachusetts Agricultural Experiment Station: Amherst, MA, USA, 1916.

33. Franklin, H.J. Cranberry Growing in Massachusetts, Extension Leaflet No. 72; Massachusetts Agricultural College: Amherst, MA, USA, 1923.

34. Franklin, H.J. Cranberry Growing in Massachusetts; Bull. No. 447; Massachusetts Agricultural Experiment Station: Amherst, MA, USA, 1948.

35. Franklin, H.J. A state owned cranberry bog. Proc. Am. Cranberry Grow. Assoc. 1915, 45, 10-14.

36. Beckwith, C.S. Report of the Cranberry Substation: Effect of fertilizer applications other than on the yield. Proc. Am. Cranberry Grow. Assoc. 1921, 51, 8-9.

37. Anonymous. Oil vitriol advertisement. Proc. Am. Cranberry Grow. Assoc. 1915, 45, 28.

38. Beckwith, C.S.; Fiske, J.G. Weeds of Cranberry Bogs, Circular No. 171; New Jersey Agricultural Experiment Station: New Brunswick, NJ, USA, 1925.

39. Hall, C.J. Fresh from the fields: Massachusetts weed control chart. Cranberries 1937, 2, 3.

40. Franklin, H.J.; Sawyer, W.H.; Cross, C.E.; Urann, M.M. Cranberry Bog Weeds; Cranberry Canners, Inc.: Barnstable, MA, USA, 1937; (estimated).

41. Cross, C.E. Chemical weed control on cranberry bogs. Proc. Am. Cranberry Grow. Assoc. 1937, 68, 3-8.

42. Peterson, G.E. The discovery and development of 2,4-D. Agric. Hist. 1967, 41, 243-253.

43. Troyer, J.R. In the beginning: The multiple discovery of the first hormone herbicide. Weed Sci. 2001, 49, $290-297$. [CrossRef]

44. Zimdahl, R.L. A History of Weed Science in the United States; Elsevier: Burlington, MA, USA, 2010.

45. Cross, C.E. Weeds of the Massachusetts Cranberry Bogs. SPart 1-The Grasses; Bull. No. 463; Massachusetts Agricultural Experiment Station: Amherst, MA, USA, 1952.

46. Janzen, M.R. The Cranberry Scare of 1959: The Beginning of the End for the Delaney Clause. Ph.D. Thesis, Texas A.\&M. University, College Station, TX, USA, 2011.

47. Gilmore, C. The great cranberry scare: They also called it black and blue Monday. Cranberries 1989, 53, 6-9.

48. Hall, C.J. Progress report on cranberry situation. Cranberries 1960, 24, 1-2, 14.

49. Shaner, D.L. Herbicide Handbook, 10th ed.; Weed Science Society of America (WSSA): Lawrence, KS, USA, 2014.

50. Hull, H.M. Herbicide Handbook, 1st ed.; Humphrey Press: Madison, WI, USA, 1967.

51. Devlin, R.M.; Demoranville, I.E. Influence of dichlobenil on yield, size, and pigmentation of cranberries. Weed Sci. 1968, 16, 38-39.

52. Devlin, R.M.; Demoranville, I.E. Influence of devrinol (R-7465) on cranberry vine growth and crop. Proc. Northeast Weed Contr. Conf. 1973, 27, 240-243.

53. Devlin, R.M.; Demoranville, I.E. Tolerance of cranberry (Vaccinium macrocarpon Ait.) to alachlor and two fluorinated pyridazinone herbicides. HortScience 1971, 6, 245.

54. Devlin, R.M.; Deubert, K.H. Use of glyphosate on cranberry bogs and its extraction from cranberries. Proc. Northeast Weed Sci. Soc. 1980, 34, 275-280.

55. Demoranville, I.E. Weeds of Massachusetts Cranberry Bogs, Part 1; University of Massachusetts: East Wareham, MA, USA, 1984; p. 22.

56. Demoranville, I.E. Weeds of Massachusetts Cranberry Bogs, Part 2; University of Massachusetts: East Wareham, MA, USA, 1986; p. 24.

57. Mahr, S.E.R.; Moffitt, L.J. Biologic and Economic Assessment of Pesticide Usage in the Cranberry Industry. NAPIAP Report, No. 2-CA-94; USDA: Washington, DC, USA, 1994; p. 95.

58. Patten, K.; Wang, J.; Katz, F.; Riemer, D.; Kusek, C.C.; Hopen, H. Cranberry tolerance to clopyralid. HortScience 1994, 29, 1131-1132.

59. Majek, B.A. Quinclorac for dodder control in cranberries. Proc. Northeast Weed Sci. Soc. 2010, 64, 40.

60. Majek, B.A.; Ayeni, A.O. Utilization of mesotrione for weed control in cranberries. Proc. Northeast Weed Sci. Soc. 2004, 58, 145.

61. Patten, K.D. Perennial and annual weed control in cranberries with vinegar, mesotrione, and chlorimuron. In North American Cranberry Researchers and Workers Conference; The University of Massachusetts (UMass) Cranberry Station: East Wareham, MA, USA, 2003.

62. Sandler, H.A. Integrating conventional and alternative practices in weed management in cranberries. Acta Hort. 2009, 810, 429-436. [CrossRef] 
63. Sandler, H.A.; Ghantous, K.M. Weed Management in Cranberry Chart Book: Management Guide for Massachusetts. Available online: http:/ /scholarworks.umass.edu/cranchart/262/ (accessed on 21 August 2018).

64. Bewick, T.A.; Binning, L.K.; Dana, M.N. Control of swamp dodder in cranberry. HortScience 1989, $24,850$.

65. Yarborough, D.E. Evaluation of preemergence herbicides for grass suppression in lowbush blueberry fields. Proc. Northeast Weed Sci. Soc. 1989, 43, 152.

66. EPA. Human Health Risk Assessment for Registration Review and to Support New Section 3 Use on Leaf Lettuce; Decision Number: D493477; Office of Prevention, Pesticides, and Toxic Substances, U.S. Environmental Protection Agency: Washington, DC, USA, 2015.

67. Wijnja, H.; Massachusetts Department of Agriculture, Boston, MA, USA. Personal communication, 2017.

68. Morrison, J.R.; Sandler, H.A.; Romaneo, L.K. Management of swamp dodder (Cuscuta gronovii Willd.) in cranberry may be enhanced by the integration of a nontoxic household cleaner. Crop Prot. 2005, 24, 1-6. [CrossRef]

69. Sandler, H.A.; Ghantous, K.M. Evaluation of Corn Gluten Meal for Preemergence Weed Management in Cranberry SARE ONE 13-193. Available online: http:/ / scholarworks.umass.edu/cranberry_research_repts/ 12 (accessed on 23 July 2018).

70. Bewick, T.A.; Stewart, J.S.; Binning, L.K.; Stevenson, W.R. Biological Control of Dodder. Patent No. 4915726; Application No. 07/010208, 10 April 2009.

71. Sandler, H.A.; Caruso, F.L.; Mika, J.S.; Colquhoun, J.B.; Cascino, J. Results from a pilot program using Smolder (Alternaria destruens) as a biological control agent for dodder. Proc. Northeast Weed Sci. Soc. 2010, 64, 56-59.

72. Cook, J.C.; Charudattan, R.; Zimmerman, T.W.; Rosskopf, E.; Stall, W.M.; MacDonald, G.E. Effects of Alternaria destruens, glyphosate, and ammonium sulfate individually and integrated for control of dodder (Cuscuta pentagona). Weed Technol. 2009, 23, 550-555. [CrossRef]

73. Caruso, F.; University of Massachusetts Cranberry Station, East Wareham, MA, USA. Unpublished data. 2018.

74. Norman, M.A.; Patten, K.D.; Gurusiddaiah, S. Evaluation of a phytotoxin(s) from Pseudomonas syringae for weed control in cranberries. HortScience 1994, 29, 1475-1477.

75. Tjiurutue, M.C.; Sandler, H.A.; Kersch-Becker, M.F.; Theis, N.; Adler, L.S. Cranberry resistance to dodder parasitism: Induced chemical defenses and behavior of a parasitic plant. J. Chem. Ecol. 2016, 42, 95-106. [CrossRef] [PubMed]

76. Tjiurutue, M.C.; Sandler, H.A.; Kersch-Becker, M.F.; Theis, N.; Adler, L.S. Gypsy moth herbivory induced volatiles and reduced parasite attachment to cranberry hosts. Oecologia 2017, 185, 133-145. [CrossRef] [PubMed]

77. Sandler, H.A.; Mason, J. Efficacy of flooding for the control of dodder (Cuscuta gronovii) and several broadleaf species in commercial cranberry production in Southeastern Massachusetts: A. two-year study. Proc. Northeast Weed Sci. Soc. 2004, 58, 163.

78. Cockfield, S.D.; Mahr, D.L. Flooding cranberry beds to control blackheaded fireworm (Lepidoptera: Tortricidae). J. Econ. Ent. 1992, 85, 2383-2388. [CrossRef]

79. O'Connell, J.; Sandler, H.A.; Adler, L.S.; Caruso, F.L. Controlled studies further the development of practical guidelines to manage dodder (Cuscuta gronovii) in cranberry production with short-term flooding. Renew. Agric. Food Syst. 2011, 26, 269-275. [CrossRef]

80. Ghantous, K.M.; Sandler, H.A.; Autio, W.R.; Jeranyama, P. Response of cranberry vines to hand-held flame cultivators. HortScience 2013, 48, 870-874.

81. Sandler, H.A.; Ghantous, K. Economics of Using Hand-Held Flame Cultivators for Weed Management in Cranberry. Available online: http:/ / wssaabstracts.com/public/4/abstract-142.html (accessed on 10 July 2013).

82. Ghantous, K.M.; Sandler, H.A. Effects of timing and frequency of flame cultivation for dewberry control. Weed Technol. 2016, 30, 751-757. [CrossRef]

83. Ghantous, K.M.; Sandler, H.A. Handheld flame cultivators for spot treatment control of soft rush (Juncus effusus). Weed Technol. 2015, 29, 121-127. [CrossRef]

84. Sandler, H.A.; Else, M.J.; Sutherland, M. Application of sand for inhibition of swamp dodder (Cuscuta gronovii) seedling emergence and survival on cranberry (Vaccinium macrocarpon) bogs. Weed Technol. 1997, 11, 318-323. [CrossRef]

85. Mason, J.; Sandler, H.A.; Hunsberger, L.K. Evaluation of sand stockpiles as potential sources of cranberry weeds. Weed Technol. 2006, 20, 58-66. [CrossRef] 
86. Ghantous, K.M.; Sandler, H.A.; University of Massachusetts Cranberry Station, East Wareham, MA, USA. Unpublished data. 2011.

87. Bewick, T.A.; Porter, J.C.; Warrick, D.M. Raking is ineffective as a means of mechanical control of dodder (Cuscuta gronovii) in cranberry. Weed Science Society of America Annual Meeting Abstracts 1999, 39, 105.

88. Hunsberger, L.K.; Autio, W.R.; DeMoranville, C.J.; Sandler, H.A. Mechanical removal of summer dodder infestations and impacts on cranberry yield. HortTechnology 2006, 16, 78-82.

89. Harding, D.P.; Raizada, M.N. Controlling weeds with fungi, bacteria, and viruses: A review. Front. Plant Sci. 2015, 6, 659-672. [CrossRef] [PubMed]

90. Ziska, L.H.; Sicher, R.C.; George, K.; Mohan, J.E. Rising atmospheric carbon dioxide and potential impacts on the growth and toxicity of poison ivy (Toxicodendron radicans). Weed Sci. 2007, 55, 288-292. [CrossRef]

91. Ramesh, K.; Matloob, A.; Aslam, F.; Florentine, S.K.; Chauhan, B.S. Weeds in a changing climate: Vulnerabilities, consequences, and implications for future weed management. Front. Plant Sci. 2017, 8, 95. [CrossRef] [PubMed]

92. Ziska, L.H. The role of climate change and increasing atmospheric carbon dioxide on weed management: Herbicide efficacy. Agric. Ecosys. Environ. 2016, 231, 304-309. [CrossRef]

93. Matzrafi, M.; Seiwert, B.; Reemtsma, T.; Rubin, B.; Peleg, Z. Climate change increases the risk of herbicide-resistant weeds due to enhanced detoxification. Planta 2016, 244, 1217-1227. [CrossRef] [PubMed]

94. Dong, F.; Mitchell, P.D.; Colquhoun, J. Measuring farm sustainability using data envelope analysis with principal components: The case of Wisconsin cranberry. J. Environ. Manag. 2015, 147, 175-183. [CrossRef] [PubMed]

95. Wolfert, S.; Ge, L.; Verdouw, C.; Bogaardt, M.J. Big Data in Smart Farming-A review. Agric. Syst. 2017, 153, 69-80. [CrossRef]

96. Saaty, T.L. Decision making with the analytic hierarchy process. Int. J. Serv. Sci. 2008, 1, 83-98. [CrossRef]

97. Sandler, H.A. Managing Cuscuta gronovii (swamp dodder) in cranberry requires an integrated approach. Sustainability 2010, 2, 660-683. [CrossRef]

98. Sandler, H.A.; Ghantous, K.M. Integrating Decision Making Processes into Cranberry Weed Management: Dodder as a Case Study. Available online: http://wssaabstracts.com/public/xx/proceedings.html (accessed on 23 July 2018).

99. Saaty, T.L.; Peniwati, K. Group Decision Making: Drawing Out and Reconciling Differences; RWS Publications: Pittsburgh, PA, USA, 2012.

100. Van Evert, F.K.; Fountas, S.; Jakovetic, D.; Crnojevic, V.; Travlos, I.; Kempenaar, C. Big Data for weed control and crop protection. Weed Res. 2017, 57, 218-233. [CrossRef]

101. Colquhoun, J.; University of Wisconsin-Madison, Madison, WI. Personal communication, 2018.

102. Charudattan, R.; DeValerio, J.T.; Pettersen, M.S. Biological control of tropical soda apple with plant pathogens and integration of biological control with other management options. Weed Sci. 2001, 41, 80.

103. Porter, J.C.; Bewick, T.A.; Warrick, D. Controlling perennial cranberry bog weeds with pruner-applied herbicides. Proc. Northeast Weed Sci. Soc. 1999, 53, 1.

104. AUVSI. The Economic Impact of Unmanned Aircraft Systems Integration in the United States Association for Unmanned Vehicle Systems International. Available online: http:/ / www.auvsi.org/auvsiresources/ economicreport (accessed on 1 February 2017).

105. American Farm Bureau Federation and Measure Produce First Ever Report and Calculator on Value of Drones in Agriculture. Available online: http:/ / www.measure.aero/measure-afbf-roicalculator-drones-precisionag (accessed on 1 February 2017).

106. Oudemans, P.V.; Rahman, F.; Hughes, M.G.; Pozdnyakova, L. GIS and remote sensing for detecting yield loss in cranberry culture. J. Nemat. 2002, 34, 207-212.

107. Oudemans, P.V.; Polashock, J.; Vinyard, B.T. Fairy ring disease of cranberry: Assessment of crop losses and impact on cultivar genotype. Plant Dis. 2008, 92, 616-622. [CrossRef]

(C) 2018 by the author. Licensee MDPI, Basel, Switzerland. This article is an open access article distributed under the terms and conditions of the Creative Commons Attribution (CC BY) license (http:/ / creativecommons.org/licenses/by/4.0/). 